\title{
Balanced Nutrition Practiced with Limitations during the COVID-19 Pandemic: The Experience of Teachers in Subang District, West Java, Indonesia
}

\author{
Avita Aliza Usfar, Ju Lan Phan \\ Dakra Consultant, Jakarta, Indonesia \\ Email: ausfar@cbn.net.id
}

How to cite this paper: Usfar, A.A. and Phan, J.L. (2022) Balanced Nutrition Practiced with Limitations during the COVID-19 Pandemic: The Experience of Teachers in Subang District, West Java, Indonesia. Open Journal of Preventive Medicine, 12, 10-29.

https://doi.org/10.4236/ojpm.2022.121002

Received: December 16, 2021

Accepted: January 24, 2022

Published: January 27, 2022

Copyright $\odot 2022$ by author(s) and Scientific Research Publishing Inc. This work is licensed under the Creative Commons Attribution International License (CC BY 4.0).

http://creativecommons.org/licenses/by/4.0/

\begin{abstract}
The purpose of the study is to assess the knowledge on Balanced Nutrition and its practices among pre-school teachers in Subang district, West Java, Indonesia before and during the COVID-19 pandemic (before March 2020 vs. October 2021) and to seek differences in the knowledge and practices of teachers who attended nutrition training and those who did not attend any nutrition training. We evaluated the knowledge and practice of 142 teachers based on 10 messages of the 2014 Indonesian Balanced Nutrition Guidelines, using google online survey platform. The top three messages mostly selected by the teachers were consuming a variety of staple foods (87\%), drinking adequate and safe water (87\%), and eating plenty of vegetables and fruits (86\%), while the least selected were enjoying a variety of foods $(41 \%)$ and reading food labels (28\%). A slight increase was found in teachers who consumed fruits daily, while the practice of washing hands before and during the pandemic was statistically and significantly increased $(58 \%$ to $72 \%$; $p<0.05)$. A slight decrease was found in teachers who consumed vegetables and animal protein, as well as performed physical exercise daily. Majority of teachers (80\%) participated in some kinds of nutrition training in the last four years. The top three gaps of knowledge between trained and non-trained teachers were on physical activity and maintaining ideal body weight (64\% vs. $33 \%$; statistically significant at $\mathrm{p}<0.05$ ); limit intake of sweet, salty, and fatty food; and consuming high protein food, with the range between 20 to 35 percentage points. We concluded that teachers acquired knowledge on nutrition to some degree, but its application faced limitations during the pandemic. Dissemination of Balanced Nutrition should continue.
\end{abstract}




\section{Keywords}

Balanced Nutrition, Knowledge, Practice, Training, Indonesia

\section{Introduction}

Worldwide, countries have developed Food-Based Dietary Guideline (FBDG), a country-specific advice on healthy diets and lifestyles based on its public health and nutrition priorities. The Food and Agriculture Organization of the United Nations (FAO) and World Health Organization (WHO) have been promoting FBDG since 1992 [1]. The guidelines which are found universal across 90 countries are to consume a variety of foods; to consume fruits and vegetables, legumes, and animal-source foods; and to limit sugar, fat, and salt [2]. The WHO guideline on Healthy Diet, which is a more current advice, consists of, among others, to consume fruits, vegetables, legumes, nuts, and whole grains, and to limit the consumption of free sugar, fat, and salt [3]. In practice, however, our diets are still not healthy. Fruit and vegetable intake is about $50 \%$ below the recommended level of five servings per day and our legume and nuts intakes are more than two thirds below the recommended two servings per day [4]. On the contrary red and processed meat intake is above the recommended one serving per week and consumption of sugary drinks increased.

With the Coronavirus disease 2019 (COVID-19) pandemic declared a global public health emergency in January 2020 [5], 97 million more people are now living in poverty [6]. The global recession had caused unemployment, income lost, lower chance of earning additional income, and less purchasing power. A decline in income reduced demand for food and altered the mix of products consumed, such as less consumption of nutrient-rich foods (animal-sourced food, fruits, vegetables), but more of calorie-rich foods (grains and sugar) [7]. The detrimental effect of the pandemic on diet quality and food insecurity was identified in 35 studies from 13 countries [8].

The Indonesian Balance Nutrition Guidelines were released by the Ministry of Health in 2014 [9], consisting of four pillars and 10 messages. The four pillars are (1) eat a variety of foods, (2) practice a clean and healthy lifestyle, (3) have an active lifestyle and exercise, and (4) maintain an ideal body weight. The 10 messages embedded in the guidelines are (1) eat a variety of staple foods, (2) eat high protein foods, (3) drink adequate and safe water, (4) wash hands with soap and running water, (5) perform adequate physical activity and maintain an ideal body weight, (6) limit consumption of sweet, salty, and fatty foods, (7) eat breakfast, (8) read food labels, (9) enjoy a variety of food, and (10) eat plenty of vegetables and fruits. This national campaign, among others, included face-to-face or online training which consisted of nutrition and health messages to pre-school education teachers [10]. The role of the Early Childhood Education Development (ECED) center is important in shaping children's dietary and healthy ha- 
bits, as eating behavior that is developed during childhood will be sustained until adolescence and adulthood [11]. A preventive approach can cancel out the cost of undernutrition, which can be as high as $11 \%$ of Gross Domestic Product (GDP) [12], or about USD 116 billion using GDP 2020 [13], along with the economic loss due to Non-Communicable Diseases (NCD), which is approximated to USD 250 billion per year [14].

With the COVID-19 pandemic declared a public health emergency in March 2020 [15], the pandemic has disrupted the country's economic and social system. The national poverty level, which had decreased from 11\% in 2015 to $9 \%$ in 2019 , increased again to $10 \%$ in 2020 [16]. An online survey conducted by the Center of Socio-Economic and Agriculture Policy to 1007 people in June 2020 found that $78 \%$ of respondents had decreased income, $89 \%$ reported that the pandemic had impacted their food consumption, and 50\% had reduced their food diversity [17]. In the same year, a study carried out by a local Non-Government Organization (NGO), Wahana Visi Indonesia, found that food consumed by $96 \%$ of children under the age of two years did not meet its required quantity and diversity [16]. The Large-Scale Social Restriction policy had affected the activities of the village Integrated Health Post (known locally as Pos Pelayanan Terpadul Posyandu), which acted as a local backbone to young children's community growth monitoring and development activity. More than one-third (37\%) of Posyandu reduced their services, and 44\% delayed its services [18]. Teaching activities of ECED were fragmented as well, i.e. stopped or converted to study from home (known locally as Belajardari Rumah/BDR) between March and June 2020, became a combination of online and offline from September to December 2020, fully online from January to August 2021, and a combination of online and offline again starting from September 2021 [19]. To compensate for the situation faced by the vulnerable population, the Indonesian government strengthened its existence social assistance program, such as the Family Hope Program (known locally as Program Keluarga Harapan/PKH) assistance to families with schoolchildren and the elderly-and the Nine Basic Food program (known locally as SEMBAKO) - provision of nine basic food needs-in addition to increasing coverage of its cash assistance program and providing electrical assistance [16].

The purpose of the study is to assess the knowledge on Balanced Nutrition and its practices among pre-school teachers who reside in Subang district, West Java province. Furthermore, we seek differences in the knowledge and practices of teachers who attended nutrition training and those who did not attend any nutrition training. The Subang district covers an area of $2051 \mathrm{~km}^{2}$, and is divided into 30 sub-districts, with a population of about 1.6 million inhabitants. The workforce is mainly occupied in services (54\%), followed by agriculture (28\%) and industry (19\%) [20]. There are 1313 pre-school institutions in Subang [21]. To increase the knowledge of the teachers, of which about one-third are high school graduates, the district pre-school association (known locally as Himpu- 
nan Pendidikan Anak Usia Dinil HIMPAUDI) worked together with other institutions to organize Balanced Nutrition trainings beginning in 2018.

\section{Methodology}

Data was collected using google online survey platform. The questionnaire consisted of socio-demographic information, knowledge, and practice questions related to Balanced Nutrition before and during the COVID-19 pandemic. "Before the pandemic" referred to the time before March 2020, and "during the pandemic" referred to September or October 2021, at the time of the survey. The direct target participants were 403 pre-school teachers in Subang district who had participated in Nutrition training between 2018 and 2021, and whose phone numbers are listed in the participants' list. The indirect participants were pre-school teachers within the district, as the study is open to all pre-school teachers within the district.

The socio-demographic questions gathered information about age, education, number of children, sex, and household expenditure. The questions related to the knowledge consisted of a list of 10 sentences, whereby the respondents should select sentences that include in Balanced Nutrition messages. The questions related to the practice included information on type of staple food consumed, daily meal and snacking frequency, consumption of animal protein, vegetables, fruits, and water, as well as handwashing and physical activity. The questionnaire had several types of possible answers, namely one choice answer, yes/no, agree/disagree, or multiple answers.

We implemented several approaches to maximize responses:

1) Distribution of the information and link to the questionnaire by the researchers. This was implemented using two methods, namely social media and direct messaging using WhatsApp (WA) or Short Messaging Service (SMS). The announcement of the survey and the link was posted in a Facebook group consisting of teachers and parents, with a total of 1,104 members. This information was posted on September 23, 2021. The direct messaging was sent to 403 teachers between September 28 and October 3, 2021. Teachers with no access to WhatsApp were sent an SMS.

2) Distribution of the information and link to the questionnaire by members of the district pre-school association using social media. The distribution was implemented through six WhatsApp groups, namely one group of the sub-district head of the pre-schools with a total of 30 people, three WhatsApp groups of 132 teachers who had previously participated in one of the Balanced Nutrition trainings, and two WhatsApp groups consisting of 80 members of the sub-district association. The total outreach was 242 teachers, and the WhatsApp was sent on September 23 and 24, 2021. In addition, the teachers were suggested to forward the link to other pre-school teachers in their schools, or to those who did not attend any of the training.

3) Re-posting on social media and reminders. The announcement was 
re-posted on Facebook on October 4 and 12, 2021. A reminder through direct personal message was sent via WhatsApp or SMS to the 403 teachers on October 7, 2021. Teachers with no access to WhatsApp were sent an SMS.

The respondents had the freedom to participate in the survey. Those who participated answered a consent question at the beginning of the questionnaire. The study received ethical approval from Atmajaya University, Jakarta number 0029V/III/LPPM-PM.10.05/09/2021. From the first 20 respondents, the average survey time was 15 minutes. We did not follow-up on whether the message was received by the target respondents, or whether the phone number is no longer active. All responses were recorded in a Google Form database. The answers were anonymous, and no names were recorded. The link to the questionnaire was closed after three weeks, or on October 14, 2021. As an incentive, phone credits of IDR 20,000 (approximately USD 1.30) were given to all respondents. The data was analyzed using Microsoft Excel Software Version 2010 (Microsoft.com, USA). Statistical tests were performed to analyze the difference in knowledge and practice before vs. during the pandemic.

\section{Results}

The Results section will be divided into three segments, namely socio-demographic characteristics, knowledge and practices of Balanced Nutrition by the teachers, and the differences in knowledge and practices of Balanced Nutrition by teachers who received vs. did not receive nutrition training.

\subsection{Socio-Economic Characteristics}

We received a total of 142 responses, or 35\% from the 403 target teachers. Most (94\%) of the respondents were female, with an average age of 38 years (ranging 18 to 56 years), had 1 to 2 children, and were high school graduates (56\%); Table 1. The pandemic had affected the economic condition of the teachers, and thus their food expenditure. About two-thirds (65\%) of the teachers experienced a decrease of income, $44 \%$ decreased their food expenditure, and one-third experienced food shortage. More than half of the teachers (56\%) admitted that their food quality had been better before the pandemic. Teachers with monthly food expenditure in the lowest range (IDR 300,000 to 1 million or approximately USD 20.00 to 67.00 ) increased from $25 \%$ to $33 \%$ before and during the pandemic, respectively. Likewise, teachers with food expenditure within the highest range (IDR 1.6 to 4 million or approximately USD 107.00 to 267.00) decreased from $30 \%$ to $20 \%$ before and during the pandemic, respectively.

About three-fourths of the teachers (73\%) received some type of social assistance during the pandemic. There were four types of assistance reported by the teachers, namely cash assistance, electrical assistance, worker's card, and provision of basic food needs (locally called SEMBAKO). Almost half of all the teachers (43\%) received cash assistance provided by the central government, $7 \%$ from the village fund, $8 \%$ for micro-business, and $9 \%$ as income subsidy. Each teacher who be 
Table 1. Socio-economic characteristics of the teachers.

\begin{tabular}{|c|c|c|}
\hline Socio-economic characteristics & \multicolumn{2}{|c|}{ Findings $(\%)(n=142)$} \\
\hline \multicolumn{3}{|l|}{ Education } \\
\hline Junior High School & \multicolumn{2}{|c|}{1} \\
\hline High school & \multicolumn{2}{|c|}{56} \\
\hline University degree & \multicolumn{2}{|c|}{43} \\
\hline \multicolumn{3}{|l|}{ Income during the pandemic compared to before the pandemic } \\
\hline Decreased & \multicolumn{2}{|c|}{65} \\
\hline Increased & \multicolumn{2}{|c|}{1} \\
\hline Remained the same & \multicolumn{2}{|c|}{34} \\
\hline $\begin{array}{l}\text { Food expenditure during the pandemic decreased compared to before } \\
\text { the pandemic }\end{array}$ & \multicolumn{2}{|c|}{44} \\
\hline Experienced food shortage during the pandemic & \multicolumn{2}{|c|}{33} \\
\hline Poorer food quality during the pandemic & \multicolumn{2}{|c|}{56} \\
\hline Monthly expenditure & Before the pandemic & During the pandemic \\
\hline USD $20.00-67.00$ & 25 & 33 \\
\hline USD $67.00-107.00$ & 44 & 46 \\
\hline USD $107.00-267.00$ & 30 & 20 \\
\hline Irregular & 1 & 1 \\
\hline \multirow[t]{2}{*}{ Received social assistance } & \multicolumn{2}{|c|}{78} \\
\hline & \multicolumn{2}{|c|}{$\mathrm{n}=104$} \\
\hline Cash & \multicolumn{2}{|c|}{67} \\
\hline Electric subsidy & \multicolumn{2}{|c|}{36} \\
\hline Worker's card & \multicolumn{2}{|c|}{11} \\
\hline Basic food needs & \multicolumn{2}{|c|}{26} \\
\hline
\end{tabular}

longed to the cash assistance program received IDR 600,000 (approximatelyUSD 40.00) per month from April to December 2020. About one-third (36\%) of the teachers received electric subsidy. The monthly fee for houses with $450 \mathrm{VA}$ was free, while there was a $50 \%$ discount for houses with 900 VA from April to December 2020 . Another $11 \%$ of the teachers received worker's card (known locally as kartu kerja), which contains an IDR 1 million (approximately USD 67.00) for training purposes and IDR 600,000 (approximately USD 40.00) per month for transport for the period of April to October 2020. Basic food needs, such as rice and egg were received by about one-fourth of the teachers and distributed through local kiosk (known locally as e-warong).

\subsection{Knowledge and Practice of Balanced Nutrition by Teachers}

The top three Balanced Nutrition messages which were mostly selected by the teachers were consuming a variety of staple foods (87\%), drinking adequate and safe water (87\%), and eating plenty of vegetables and fruits (86\%) (Table 2). The majority teachers acknowledged that washing hands with soap and running water $(78 \%)$, consuming high protein source food (71\%), and eating breakfast (65\%) was also part of Balanced Nutrition messages. Fewer teachers, however, selected physical activity and maintained ideal body weight, as well as limit 
Table 2. Knowledge on balanced nutrition of teachers who attended vs. not attended training.

\begin{tabular}{|c|c|c|c|}
\hline Balanced Nutrition Messages & $\begin{array}{l}\text { Attended training } \\
\qquad(\mathrm{n}=118)\end{array}$ & $\begin{array}{l}\text { Not attended } \\
\text { training } \\
(\mathrm{n}=24)\end{array}$ & $\begin{array}{c}\text { Total } \\
(\mathrm{n}=142)\end{array}$ \\
\hline 1) Eat a variety of staple foods (\%) & 89 & 75 & 87 \\
\hline 2) Eat plenty of vegetables and fruits (\%) & 88 & 75 & 86 \\
\hline 3) Drink adequate and safe potable drinking water (\%) & 87 & 75 & 87 \\
\hline 4) Wash your hands with soap and running water (\%) & 80 & 71 & 78 \\
\hline 5) Eat high protein-source food (animal and plant based) (\%) & 74 & 58 & 71 \\
\hline $\begin{array}{l}\text { 6) Perform adequate physical activity and maintain an ideal } \\
\text { body weight }(\%)^{*}\end{array}$ & 64 & 33 & 58 \\
\hline 7) Limit intake of sweet, salty, and fatty foods (\%) & 56 & 38 & 52 \\
\hline 8) Eat breakfast (\%) & 65 & 63 & 65 \\
\hline 9) Enjoy a variety of foods (\%) & 40 & 46 & 41 \\
\hline 10) Read food labels (\%) & 27 & 33 & 28 \\
\hline
\end{tabular}

${ }^{\star}$ Significant difference at $\mathrm{p}<0.05$ using chi-square test.

intake of sweet, salty, and fatty food, as being part of Balanced Nutrition messages. The least-selected messages were: enjoy a variety of foods and reading food labels. As rice is the main staple food in Indonesia, almost all teachers consumedrice before and during the pandemic. About half of all the teachers included noodles as one the two main staple foods aside from rice. Other staple foods mentioned were wheat and rice flour-based processed food, and tubers (sweet potatoes, cassava, and potatoes).

There was a gap between the knowledge and practice of eating vegetables and fruits. Although the teachers recognized the importance of consuming vegetables every day, only about one-fourth of them consumed vegetables on a daily basis (Table 3). From those who did not consume them daily, the majority consumed vegetables three times or less per week. The majority of the teachers consumed one to two portions of vegetables, with more teachers consuming one portion. The consumption of vegetables tended to decrease from one portion to less than one portion during the pandemic. In general, consumption of fruits was less than that of vegetables. Teachers who consumed fruits daily were about one-fifth of the respondents. From those who did not consume fruits daily, they consumed them three days or less per week. Most teachers consumed less than, or equal to, two portions. The practice of drinking at least seven glasses of water daily was implemented by most teachers, and slightly increased during the pandemic.

The practice of washing hands at four critical times was implemented by about half of the teachers before the pandemic but increased to about three-fourths of the teachers during the pandemic. The increased was statistically significant at $\mathrm{p}<0.05$. The suggested four critical times for handwashing with 
Table 3. Practices on balanced nutrition of trained and non-trained teachers before and during the COVID-19 pandemic.

\begin{tabular}{|c|c|c|c|c|c|c|}
\hline \multirow{2}{*}{ Balanced Nutrition Messages } & \multicolumn{2}{|c|}{$\begin{array}{l}\text { Attended training } \\
\qquad(\mathrm{n}=118)\end{array}$} & \multicolumn{2}{|c|}{$\begin{array}{l}\text { Not Attended training } \\
\qquad(\mathrm{n}=24)\end{array}$} & \multicolumn{2}{|c|}{ Total $(n=142)$} \\
\hline & $\begin{array}{l}\text { Before the } \\
\text { pandemic }\end{array}$ & $\begin{array}{l}\text { During the } \\
\text { pandemic }\end{array}$ & $\begin{array}{l}\text { Before the } \\
\text { pandemic }\end{array}$ & $\begin{array}{l}\text { During the } \\
\text { pandemic }\end{array}$ & $\begin{array}{l}\text { Before the } \\
\text { pandemic }\end{array}$ & $\begin{array}{l}\text { During the } \\
\text { pandemic }\end{array}$ \\
\hline $\begin{array}{l}\text { Included rice as one of the staple } \\
\text { food components (\%) }\end{array}$ & 95 & 97 & 92 & 96 & 94 & 96 \\
\hline $\begin{array}{l}\text { Included noodle as the two top } \\
\text { staple food choices (\%) }\end{array}$ & 47 & 54 & 38 & 50 & 46 & 54 \\
\hline $\begin{array}{l}\text { Consumption of vegetables } \\
\text { every day (\%) }\end{array}$ & 29 & 23 & 21 & 29 & 27 & 24 \\
\hline $\begin{array}{l}\text { Consumption of vegetables } \\
\text { less than or equal to } 3 \text { days } \\
\text { per week (\%) }\end{array}$ & $\begin{array}{c}\mathrm{n}=84 \\
60\end{array}$ & $\begin{array}{c}\mathrm{n}=90 \\
62\end{array}$ & $\begin{array}{c}\mathrm{n}=19 \\
62\end{array}$ & $\begin{array}{c}\mathrm{n}=17 \\
65\end{array}$ & $\begin{array}{c}\mathrm{n}=103 \\
59\end{array}$ & $\begin{array}{c}\mathrm{n}=107 \\
63\end{array}$ \\
\hline \multicolumn{7}{|c|}{ Portions or bowls of vegetables consumed per day (\%) } \\
\hline Less than 1 bowl & 9 & 19 & 21 & 21 & 11 & 20 \\
\hline 1 bowl & 44 & 36 & 63 & 58 & 47 & 39 \\
\hline 2 bowls & 33 & 34 & 17 & 17 & 30 & 31 \\
\hline 3 bowls & 11 & 10 & 0 & 4 & 11 & 9 \\
\hline More than 3 bowls & 1 & 1 & 0 & 0 & 1 & 1 \\
\hline $\begin{array}{l}\text { Consumption of fruits } \\
\text { every day (\%) }\end{array}$ & 19 & 19 & 29 & 33 & 20 & 22 \\
\hline Consumption of fruits less than & $\mathrm{n}=96$ & $\mathrm{n}=95$ & $\mathrm{n}=17$ & $\mathrm{n}=16$ & $\mathrm{n}=113$ & $\mathrm{n}=111$ \\
\hline or equal to 3 days per week (\%) & 68 & 76 & 68 & 75 & 67 & 76 \\
\hline \multicolumn{7}{|c|}{ Portions or bowls of fruits consumed per day (\%) } \\
\hline Less than 1 bowl & 19 & 26 & 25 & 29 & 20 & 27 \\
\hline 1 bowl & 42 & 39 & 50 & 50 & 43 & 41 \\
\hline 2 bowls & 29 & 28 & 21 & 21 & 27 & 25 \\
\hline 3 bowls & 8 & 8 & 4 & 0 & 8 & 7 \\
\hline More than 3 bowls & 2 & 0 & 0 & 0 & 1 & 0 \\
\hline \multicolumn{7}{|l|}{ Drinking water per day (\%) } \\
\hline 6 glasses or less & 14 & 11 & 21 & 17 & 15 & 12 \\
\hline $7-8$ glasses & 64 & 64 & 63 & 63 & 65 & 63 \\
\hline$>8$ glasses & 25 & 25 & 17 & 21 & 20 & 25 \\
\hline $\begin{array}{l}\text { Washing hands during } 4 \text { critical } \\
\text { periods }^{\mathrm{a}}(\%)\end{array}$ & 58 & 73 & 54 & 67 & 58 & $72^{\star}$ \\
\hline $\begin{array}{l}\text { Consumption of animal protein } \\
\text { every day }(\%)\end{array}$ & 76 & 69 & 50 & 54 & 73 & 67 \\
\hline
\end{tabular}




\begin{tabular}{|c|c|c|c|c|c|c|}
\hline \multirow{4}{*}{$\begin{array}{l}\text { Type of animal protein } \\
\text { consumed }\end{array}$} & Egg & \multicolumn{3}{|c|}{ Egg } & Egg & Egg increased \\
\hline & Fish & \multicolumn{3}{|c|}{ Fish } & Fish & Fish decreased \\
\hline & Chicken & \multicolumn{3}{|c|}{ Chicken } & Chicken & $\begin{array}{l}\text { Chicken } \\
\text { decreased }\end{array}$ \\
\hline & Beef & \multicolumn{3}{|c|}{ Beef } & Beef & Beef decreased \\
\hline $\begin{array}{l}\text { Physical exercise at least } 30 \\
\text { minutes per day (\%) }\end{array}$ & 49 & 42 & 46 & 54 & 49 & 44 \\
\hline $\begin{array}{l}\text { Frequency of snacking per day } \\
(\%)\end{array}$ & $\mathrm{n}=105$ & $\mathrm{n}=103$ & $\mathrm{n}=23$ & $\mathrm{n}=19$ & $\mathrm{n}=128$ & $\mathrm{n}=122$ \\
\hline Once & 20 & 35 & 22 & 32 & 20 & 34 \\
\hline Twice & 54 & 41 & 57 & 58 & 55 & 43 \\
\hline Three times & 12 & 16 & 13 & 5 & 13 & 14 \\
\hline More than 3 times & 13 & 9 & 9 & 5 & 13 & 8 \\
\hline \multicolumn{7}{|l|}{ Daily meal frequency (\%) } \\
\hline Once & 1 & 1 & 8 & 8 & 2 & 2 \\
\hline Twice & 29 & 44 & 46 & 46 & 32 & 44 \\
\hline Three times & 70 & 53 & 46 & 46 & 66 & 51 \\
\hline More than 3 times & 0 & 3 & 0 & 0 & 0 & 2 \\
\hline
\end{tabular}

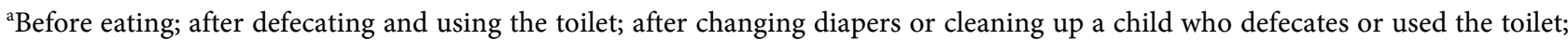
and before, during, and after preparing food. ${ }^{\star}$ significant difference at $\mathrm{p}<0.05$ before and during the pandemic using $\mathrm{t}$-test.

soap were: (1) before eating, (2) after defecating and using the toilet, (3) after changing diapers and cleaning a child who defecates or use the toilet, and (4) before, during, and after preparing food [22]. The Ministry of Health suggested an increase from four to 13 times of handwashing with soap during the pandemic [22], which could be answered correctly by $43 \%$ of the teachers. The other nine times that one should wash his/her hands with soap under running water are: (1) after sneezing and coughing, (2) before touching the eyes, nose, or mouth, (3) after touching the surface of an object, including a door handle or a table, (4) before and after taking care of a person who vomits or has diarrhea, (5) before and after taking care of an injured person, (6) after touching animals, animal feed, and animal feces, (7) when the hands look dirty and oily, (8) before and after visiting friends or families, and (9) after touching the garbage.

Consumption of protein as part of a daily nutritious diet was practiced by majority of the teachers. The proportion of teachers who consumed protein daily decreased by six percentage points during the pandemic. The type of protein consumed, however, remained the same: egg, freshwater fish, chicken, and beef. Balanced Nutrition messages enforce breakfast as part of the daily consumption necessities. We assumed from teachers who had three meals per day that one of those meals would be breakfast. We observed a decrease in the number of teach- 
ers who had three meals per day by 15 percentage points, and an increase in the number of teachers who had meals twice per day by 12 percentage points. No information was gathered to find out whether mealtime consumed twice a day included breakfast in the morning. A decrease in the frequency of snacking was noticed, as well; the teachers who consumed snacks twice a day decreased, while those who consumed snacks once a day increased. Some of the snacks mentioned were those containing flour, such as bread, surabi (pancake), which is sometimes served as breakfast.

The decrease in daily frequency, portion size, and quality of food consumed is in line with the teachers' opinion that the pandemic had affected their food choices. About $42 \%$ of teachers had the opinion that the pandemic had made it difficult for them to access food sources, and about one-fourth (25\%) perceived that their eating portion had decreased. The majority of teachers $(69 \%)$ perceived that their daily snacking had decreased, although about the same proportion of teachers (68\%) perceived that the pandemic had increased their body weight. When asked about their coping strategies due to the decrease of income, about two-thirds (61\%) mentioned that they had reduced unnecessary expenditure. Other answers included finding additional jobs (17\%), utilizing savings and finding credits/debt (each 8\%), and $4 \%$ improved their work production.

\subsection{Knowledge and Practice of Balanced Nutrition by Trained vs. Non-Trained Teachers}

The majority of teachers (80\%) participated in some kinds of nutrition training within the last four years (2018-2021). The percentage of teachers who selected eight of the 10 Balanced Nutrition messages was higher amongst those who had attended training than it was for those who had not attended any training, with a difference of between 7 to 35 percentage points. The top three messages selected by the teachers were eat a variety of staple food (89\%), eat plenty of vegetables and fruits every day (88\%), and drink adequate and safe water (87\%); Table 2. The top three gaps of knowledge between the trained vs. non-trained teachers were for the following messages: the need to have adequate physical activity and maintain ideal body weight ( $64 \%$ vs. $33 \%$ ), limit intake of sweet, salty, and fatty food ( $56 \%$ vs. $38 \%)$ and consume high protein source food ( $74 \%$ vs. $58 \%)$. The knowledge gap was statistically significant for physical activity and maintains ideal body weight at $\mathrm{p}<0.05$. Our findings underlined that the knowledge of the trained teachers is better than that of the non-trained teachers.

Because rice is the main staple food in the area, there is basically no difference in the consumption of rice of the trained vs. non-trained teachers before and during the pandemic. The difference was found in the selection of two top staple food choices, as less of the trained teachers chose noodle compared to the non-trained ones. Noodle consumption increased by 12 percentage points, from $38 \%$ to $50 \%$, in the non-trained group (Table 3 ). Although daily consumption of vegetables was practiced by about one-fifth of the teachers, this practice increased during the pandemic among the non-trained teachers by eight percen- 
tage points. The majority of teachers consumed vegetables three days or less during the week; this is similar across groups, with relatively no change before and during the pandemic. As for the portion size, majority of both the trained and non-trained teachers consumed one to two portions of vegetables per day of consumption before the pandemic. This trend remained the same during the pandemic, with a slight decreased in the percentage of teachers consuming one portion in both groups and increased percentage of teachers consuming less than 1 portion in the trained group.

Daily consumption of fruits was considered low as well, as about one-fifth (19\%) of the trained teachers consumed them every day. The majority of teachers who did not eat fruit daily consumed them three days or less within the week. Consumption of fruits was more varied, ranging from one to three portions, and remained relatively the same during the pandemic. A slight increase was observed in teachers who consumed less than one portion during the pandemic. The majority of the teachers in both groups consumed seven to eight glasses of water per day, although the consumption of more than eight glasses was higher in the trained groups. A slight increase in water consumption can be observed in the non-trained groups.

Before the pandemic, more of the trained teachers consumed protein source food daily compared to the non-trained ones ( $76 \%$ vs. $50 \%$, respectively). During the pandemic, the trained teachers consumed it more irregularly. The common daily meal frequency was two to three times daily. More of the non-trained teachers ate once per day. Reduction of daily meal frequency can be seen more in the trained group. Snacking was very common, with majority once or twice per day. A reduction in daily snacking frequency can be seen during the pandemic. More teachers changed their snacking practice to once per day. Although physical activity for at least 30 minutes per day was carried out by about half of the teachers, the implementation decreased in the trained teachers, and increased in the non-trained teachers, during the pandemic.

\section{Discussion}

Our study found that teachers increased their vegetable and fruit consumption more during the pandemic. This is in line with other studies conducted during the pandemic, as well. A study in East Kalimantan province with university students found an increase in vegetable intake by $52 \%(n=64)$ and fruit intake by $63 \%$ [23]. Routine daily consumption of vegetables and fruits were noted in a study in Banten province (56\% and 32\% respectively), whereby about two-third of the respondents consumed 2 - 4 portions vegetables or fruits daily during the pandemic (64\% and 65\% respectively) [24]. A study in Turkey noted similar findings, whereby $41 \%$ respondents [university students] increased their vegetable intake, and $49 \%$ increased their fruit intake [25]. The Ministry of Health re-campaign Balanced Nutrition messages during the pandemic underlined the importance of nutritious food, including continued consumption of vegetables 
and fruits [26]. The promotion of vegetables and fruits reiterated their functions in providing vitamins, minerals, antioxidants, and improving the immune system. Based on a national health survey in 2018, daily consumption of adequate vegetables and fruits among people aged five years or older was 5\% [27]. Thus, an increase of daily consumption to about one-third of the teachers already constituted an improvement.

Good knowledge may not always translate into good practices, however. While the knowledge of consuming vegetables and fruits daily was understood by majority of teachers, in practice, about one-fourth consumed them on daily basis and was still inadequate in terms of quantity. About 9 out of 10 teachers in our study did not consume three portions or more of vegetables or fruits per day. This is consistent with the result of the Indonesian basic health research 2018 , which found $96 \%$ of the population aged older than 5 years did not consume five portions of vegetables and fruits a day [27]. At a global scale, $77 \%$ of men and $78 \%$ of women in 52 low-or-middle-income countries (LMIC) consumed less than the five recommended fruits and vegetables servings a day, with the average intake in low LMIC of 3.6 portions per day [28]. Furthermore, low income is a predictor of inadequate intake of vegetable and fruit consumption at a country level, as well as at the household and individual levels.

In Indonesia, especially in rural areas like Subang district, home gardens as a source of vegetables and fruits are still common. About two-thirds (63\%) of the Indonesian households utilized a home garden as a source of food [29]. Some vegetables that could be easily home-grown are spinach, water spinach, tomato, pumpkin, eggplant, mustard green, green beans, and chili, which are commonly grown in the study area. Teachers with larger home yards can use them to raise chicken or duck for alternative animal protein sources as well. The potential yield of home garden is $50 \mathrm{~kg}$ per $\mathrm{m}^{2}$ per year [30]. The $\mathrm{MoH}$ recommends 300 to 400 grams of vegetables and fruits per day for children under the age of five years, and 400 to 600 grams for adolescents and adults [9]. If a home has a $7 \mathrm{~m}^{2}$ garden, then the harvest can contribute to the consumption of one child and one adult in the family. The vegetables will contribute to the daily adequacy of vitamins and minerals and can replace sweet and salty snacks. The FAO declared 2021 as an international year of fruit and vegetables, targeting adults to consume the recommended minimum intake of 400 grams of fruits and vegetables per day [31].

Our study also found an increase of drinking water consumption during the pandemic. This is in line with a study in Banten province, which found that $66 \%$ respondents increased their water consumption during the pandemic [24]. Much of the campaign to drink more water during the pandemic was socialized through social media. Through the Ministry of Health re-campaigning of Balanced Nutrition messages during the pandemic, they underlined the importance of drinking at least eight glasses of water per day [26]. WHO is globally campaigning to "stay hydrated drink plenty of water" using the tagline "healthy at 
home" during the pandemic [32]. A study conducted by the Indonesia Water Institute (IWI) in October-November 2020, which involved 1296 respondents across Indonesia, found that clean water needs increased two-to-three-fold during the pandemic, as compared to normal conditions [33]. A study among 1334 adolescents aged 10 to 16 years in Poland found that the proportion of adolescents consuming water daily increased from $41 \%$ to $48 \%$ during the pandemic compared to sweetened beverage, due to, among others, studying at home and parents' positive influence [34].

Another key finding from this study is the increased practice of washing hands with soap. The handwashing campaign was shared through social media by many health personnel at the beginning of 2020, using blogs, Twitter, Facebook, WhatsApp, and online to reach the public. Posters and banners can be seen in many public places and public transportations. The appeal to wash hands frequently was made by the President. The promotion consisted of three points: using masks, social distancing, and washing hands with soap [35]. Government offices down to the village levels and the private companies had their share of promotion, as well. The $\mathrm{MoH}$ re-campaign of Balanced Nutrition messages during the pandemic reiterated washing hands with soap and running water as being one of the actions for preventing infection [26]. The campaign continued consistently throughout the last two years. A world day of "hand washing" was established on October 15, 2020 [35]. The association of environmental health experts (Himpunan Ahli Kesehatan Lingkungan Indonesia) organized a handwashing campaign in 10,000 loci in 2021 across the country [36].

Washing hands with soap have been part of a community-based sanitation promotion since 2008 [37], but the increase in awareness and practice improved greatly during the pandemic. A survey conducted in 2018 found that washing hands with soap a day before the survey was carried out by $33 \%$ respondents [38]. A national basic health survey in 2018 noted that 50\% respondents aged older than 10 years washed their hands with soap and running water [27]. Our study noticed an improvement of practice in up to three-fourths of the teachers. This increase is in line with another study during the pandemic which found a higher percentage of people ( $83 \%$ female and $74 \%$ male; $n=896$ ) who wash their hands with soap for more than eight times per day [39]. Additionally, a study in 108 university students in Jambi province noted the importance of peer-to-peer support in increasing handwashing practice [40].

This study supports the findings that exposure to nutrition information increased knowledge. Attendance to some type of nutrition training, either online or offline, is beneficial. Most of the teachers (93\%) attended training organized by the district pre-school association, working together with the district government, private industry, and an independent consultancy agency. The topics covered in the training varied, consisting of-among others-Balanced Nutrition, My Plate, child growth and development, food and nutrition for young children, menu preparation, and prevention of stunting. The trainings imple- 
mented between 2018 and 2019 were offline and were conversely online in 2020 and 2021. One teacher attended an online training organized by the Ministry of Education on the digitalization of health and nutrition module. Our previous study found that knowledge of Balanced Nutrition messages can be retained by the teachers 12 months post-training [41], and that the teachers still taught the information to their students 27 months post-training [42]. A study among 5,924 university students majoring in health vs non-health across Indonesia found that consumption of water 8 glasses or more per day and consumption of vegetables in every meal were implemented more in students with health major [43].

The teachers in our study seemed to understand the Balanced Nutrition message on diversification of staple food, but not on diversification of other types of food-which is reflected by the message "Enjoy a variety of food". The socialization of this message may need to be blunt, that diversification has to be done with other types of food as well, i.e. vegetables, fruits, animals, and plant source protein. Another less-understood message was "Reading food labels". Important information on the label must be explained so that they can better understand the purpose of reading the labels. We should also create demand for food to be labeled, because many home-based food manufacturers do not put labels on their products. Snacks sold in the small kiosk for example, rarely have an expiry date listed, let alone their nutrition labels. The following benefits of reading labels published by FAO can be shared during training: 1) keeping you healthy, 2) keeping you safe, 3) stopping you from buying counterfeit products, 4) detecting ingredients that could cause harmful reactions, 5) stopping you from wasting food, and 6) supporting local producers [44].

The implementation of daily household chores and exercises can be part of physical activity. The WHO advises adults aged 18 to 64 years to implement a 45-minute middle to high intensity physical activity in a day, in addition to muscle strengthening exercise minimum of two times a week [45]. Basic Health Research 2018 identified about two-third (67\%) of the Indonesians aged 10 years and above had minimum 30 minutes moderate-to-vigorous physical activity per day, at least five times a week [27]. Carrying out household chores, such as sweeping the floor, washing clothes are usually inadequate. Some examples of physical activity are walking, jogging, running, cycling, swimming, basketball, soccer, and badminton. Aerobics is an example of moderate intensity physical activity. Recreational exercises including "active" traditional dances can be counted as physical activity as well, e.g. saman, kecak, and poco-poco dance [9]. The habit of using motorcycles to travel, as it is a convenient and common practice in most suburban areas of Indonesia, could be changed to walking or cycling. This could be a good alternative to teachers whose house is close to the school. The local government could support more physical activities by facilitating the building of necessary infrastructure, such as the creation of special paths for walking and cycling at the central part of the district or badminton, basket- 
ball, and soccer field at the village level. Adequate physical activity can decrease the risk of chronic diseases in older age. An online multi-country study among 1047 adults found a reduction of physical activity in general during the pandemic, in terms walking as well as moderate and vigorous intensity activity [46]. On the other hand, daily sitting time increased from 5 to 8 hours per day.

The function of social assistance programs to balance the basic need of the vulnerable population during a time of shock was present in our study area. The social assistance program distributed by the central and district's government is targeted to prevent them from falling into poverty. The social assistance program distributed to the teachers seemed to be quite targeted. The average per capita monthly expenditure in Subang district is IDR 1,057,047 or approximately USD 70.00, in which about 56\% was spent on food [47]. Considering that the expenditure of the teachers was around this amount, we assumed that the assistance was helpful.

\section{Conclusions and Recommendations}

There are Balanced Nutrition knowledge that were still less understood or unknown by the teachers, therefore, further socialization and nutrition training are required. The messages that need to be reiterated are not only those that can be identified by the teachers, but also those that were less identified. Definite improvement is needed not only in increasing the consumption of food, but also consuming the food daily or combining them in every meal. The teachers and presumably their families need to improve their vegetables, fruits, protein, and water consumption. The future promotion of Balanced Nutrition messages should consider environmental sustainability, as formulated in FAO/WHO 2009 Sustainable Healthy Diet. The advice could include, among others, consumption of mostly plant-based food, consumption of seasonal and local foods, reduction of food waste, consumption of fish from sustainable stocks only, reduction of red and processed meat, and reduction of high processed foods and sugar-sweetened beverages [48]. In addition, they need to be more active, that is increasing their physical activity in terms of length and frequency. Further improvement in washing hands practices is necessary during the pandemic era, for example before touching the face (eyes, nose, mouth) or after touching the surface of an object.

Balanced Nutrition messages could be disseminated using digital media, such as smartphone-friendly channels and apps like YouTube, WhatsApp, and Instagram. All teachers have handphones and belong to at least one social media platform. Socialization or synthesizing of the importance of eating a variety of food should be exposed to the children and the men, as well. Better knowledge by family members would create demand for a greater variety of food served within the household. Exercise in menu preparation can be included as part of the online training. To underline the importance of the messages, the head of the district or other influential person can participate in the training and promo- 
tional activities.

Commitment of the leader is a key to a successful program. In general, every dollar invested in nutrition can generate as much as USD 160.00 in future benefits for Indonesia [49]. Teachers can act as change agents for the pre-school students and their parents. A cascade training system using a peer-to-peer facilitator can be used to accelerate the dissemination of Balanced Nutrition messages. This preventive approach could eliminate the estimated cost of improving nutrition of USD 100.00 per child [50] or the potential loss of GDP, in addition to eliminating the potential loss of poor-quality human resources. Nutrition must be considered an investment in ending the vicious cycle of generational malnutrition.

\section{Acknowledgements}

The authors thank the district pre-school association (HIMPAUDI) for their support of the study and all teachers who had responded to the questionnaire. Majority of the teachers who attended nutrition training from 2018 to 2021 participated in the training organized by HIMPAUDI and Sakanti Consulting, funded by Danone Indonesia.

\section{Conflicts of Interest}

The authors declare no conflicts of interest.

\section{References}

[1] Food and Agriculture Organization (2021) Food-Based Dietary Guidelines. https://www.fao.org/nutrition/education/food-dietary-guidelines/regions/en

[2] Herforth, A., Arimond, M., Alavariz-Sanchez, C., Coates, J., Cristianson, K. and Muehlhof, E. (2019) A Global Review of Food-Based Dietary Guidelines. Advances in Nutrition, 10, 590-605. https://doi.org/10.1093/advances/nmy130

[3] World Health Organization (2020) Healthy Diet. https://www.who.int/news-room/fact-sheets/detail/healthy-diet

[4] (2021) Development Initiative Poverty Research. Global Nutrition Report: The State of Global Nutrition. Development Initiative, Bristol. https://globalnutritionreport.org/reports/2021-global-nutrition-report

[5] World Health Organization (2020) WHO Director-General's Opening Remarks at the Media Briefing on COVID-19-11 March 2020.

https://www.who.int/director-general/speeches/detail/who-director-general-s-openi ng-remarks-at-the-media-briefing-on-covid-19---11-march-2020

[6] World Bank (2021) Updated Estimates of the Impact of COVID-19 on Global Poverty: Turning the Corner on the Pandemic in 2021?

https://blogs.worldbank.org/opendata/updated-estimates-impact-covid-19-global-p overty-turning-corner-pandemic-2021

[7] Laborde, D., Martin, W. and Vos, R. (2021) Impacts of COVID-19 on Global Poverty, Food Security, and Diets: Insights from Global Model Scenario Analysis. Agricultural Economics, 52, 375-390. https://doi.org/10.1111/agec.12624 https://www.ncbi.nlm.nih.gov/pmc/articles/PMC8251321/pdf/AGEC-52-375.pdf 
[8] Picchioni, F., Goulao, L.F. and Roberfroid, D. (2021) The Impact of COVID-19 on Diet Quality, Food Security, and Nutrition in Low-and-Middle Income Countries: A Systematic Review of the Evidence. Clinical Nutrition. https://doi.org/10.1016/j.clnu.2021.08.015

[9] Ministry of Health (2014) Ministerial Decree Number 41 on Balanced Nutrition. http://hukor.kemkes.go.id/uploads/produk_hukum/PMK\%20No.\%2041\%20ttg\%20 Pedoman\%20Gizi\%20Seimbang.pdf

[10] Ministry of Education (2021) Basic Tiered Education and Training. https://ayogurubelajar.kemdikbud.go.id/seri-paud-diklat-berjenjang-dasar

[11] Ward, S.A., Bélanger, M.F., Donovan, D. and Carrer, N. (2016) Relationship between Eating Behaviors and Physical Activity of Pre-Schoolers and Their Peers: A Systematic Review. International Journal of Behavioral Nutrition and Physical Activity, 13, 50. https://doi.org/10.1186/s12966-016-0374-x

[12] International Food Policy Research Institute (2016) Global Nutrition Report 2016: From Promise to Impact: Ending Malnutrition by 2030. Washington DC.

https://www.ifpri.org/publication/global-nutrition-report-2016-promise-impact-en ding-malnutrition-2030

https://doi.org/10.2499/9780896295841

[13] Indonesia Gross Domestic Products (2021) Trading Economics. https://tradingeconomics.com/indonesia/gdp\#: :text=Indonesia\%20GDP\%20The\% 20Gross\%20Domestic\%20Product\%20\%28GDP\%29\%20in,of\%20the\%20world\%20e conomy.\%20source\%3A\%20World\%20Bank\%2010Y\%E2\%80\%A6

[14] Bloom, D.E., Chen, S., McGovern, M., Prettner K., Candeias, V., Bernaert, A., et al. (2015) The Economics of Non-Communicable Diseases in Indonesia. Harvard T.H. Chan School of Public Health, Department of Global Health and Population, World Economic Forum.

https://www3.weforum.org/docs/WEF_The_Economics_of_non_Disease_Indonesia 2015.pdf\#: :text=The\%20costs\%20associated\%20with\%20NCDs\%20in\%20Indone sia\%20are,trillion\%20\%28or\%20\%2417\%2C863\%20per\%20capita\%292from $\% 20201$ 2\%20through\%202030

[15] President of the Republic of Indonesia (2020) President Decree Number 12 on Determination of Non-Natural Disaster the Spread of Corona Virus Diseases. https://peraturan.bpk.go.id/Home/Details/135718/keppres-no-12-tahun-2020

[16] Minister of National Development Planning (2021) Indonesia Voluntary National Review 2021 Sustainable and Resilient Recovery from the COVID-19 Pandemic for the Achievement of the 2030 Agenda.

https://sdgs.bappenas.go.id/laporan-voluntary-national-review-vnr-indonesia-2021

[17] Ariningsih, E., Erma, S. and Handewi, P.S. (2020) Food Diversification as a Household Adaptation Strategy in Facing the Covid-19 Pandemic. In: Suryana, A., I Wayan, R., Tahlim, S. and Sahat, M.P., Eds., Impact of the Covid-19 Pandemic Perspective of Agricultural Socio-Economic Adaptation and Resilience, IAARD Press, Jakarta, 761-782.

[18] Ministry of Health, Center of Research and Development (2020) Innovation to Accelerate Stunting Reduction.

https://www.litbang.kemkes.go.id/webinar-inovasi-percepatan-penurunan-stunting -di-era-pandemi-covid-19-materi-paparan-dan-dokumentasi

[19] Ministry of Education. Center of Research and Development (2021) Learning Adaption during Pandemic.

https://puslitjakdikbud.kemdikbud.go.id/assets_front/images/produk/1-gtk/materi/ Se- 
$\underline{\text { si_III_K7_Adaptasi_Pembelajaran_pada_PAUS_di_Masa_Pandemi_Covid_-_19_-- }}$ Nur_Listiawai_dkk.pdf

[20] Central Bureau of Statistics (2020) Subang District in Numbers. https://subangkab.bps.go.id/publication/2020/04/27/6e1d55142dacdec7f404746a/ka bupaten-subang-dalam-angka-2020-.html

[21] Ministry of Education (2021) Number of Early Child Education Center in Subang District. https://referensi.kemdikbud.go.id/index21.php?kode $=021900 \& l e v e l=2$

[22] Ministry of Health (2020) Handwashing Using Soap Guideline. https://kesmas.kemkes.go.id/assets/upload/dir_519d41d8cd98f00/files/Panduan_CT PS2020_1636.pdf

[23] Noviasty, R. and Susanti, R. (2020) Changes in Eating Behaviour among College Student on Nutrition Department during the Pandemic Covid-19. Jurnal Kesehatan Masyarakat Mulawarman, 2, 90-99. https://doi.org/10.30872/jkmm.v2i2.5079

[24] Mustakim, Efendi, R. and Sofiany, I.R. (2021) Dietary Patterns among Productive Age Population during Covid-19 Pandemic in South Tangerang. Jurnalllmu Kesehatan Masyarakat, 17, 1-12.

[25] Yilmaz, H.O., Azlan, R. and Unal, C. (2020) Effect of the COVID-19 Pandemic on Eating Habits and Food Purchasing Behaviors of University Students. Jurnal Kesehatan Masyarakat Nasional (National Public Health Journal), 15, 154-159. https://doi.org/10.21109/kesmas.v15i3.3897

[26] Ministry of Health (2020) Balanced Nutrition Guidelines during COVID-19 Pandemic.

https://covid19.go.id/storage/app/media/Materi\%20Edukasi/2020/Mei/final-pandua n-gizi-seimbang-pada-masa-covid-19-1.pdf

[27] Ministry of Health (2018) Basic Health Research 2018. Jakarta.

[28] Nijhuis, A. and Brouwer, I.D. (2020) Fruits and Vegetables Consumption in Lowand-Middle-Income Countries. A Comprehensive Review of Fruits and Vegetables Intake and Determinants Using a Food Systems Approach. Division of Human $\mathrm{Nu}$ trition and Health, Wageningen University and Research. Wageningen. https://a4nh.cgiar.org/files/2020/05/Review-Fruits-and-Vegetables-Intake-and-Dete rminants-LMIC_2020-FINAL.pdf

[29] Azra, A.L.Z., Hadi, S.A., Made, A. and Arifin, H.S. (2017) Characteristics Analysis of Homegarden to Support Food Consumption Diversification of the Household in Bogor Regency. Journal Landscape Indonesia, 6, 1-12.

[30] World Vegetable Research (2017) Healthier Lives, More Resilient Livelihoods: World Vegetable Center Strategy 2017-2025. World Vegetable Center, Shanhua, Publication $17-823,57 \mathrm{p}$.

[31] Food and Agriculture Organization (2021) International Year of Fruit and Vegetables 2021. https://www.fao.org/fruits-vegetables-2021/en

[32] World Health Organization (2020) \#HealthyAtHome: Healthy Diet. https://www.who.int/campaigns/connecting-the-world-to-combat-coronavirus/heal thyathome/healthyathome---healthy-diet

[33] International Water Institute (2021) Water Consumption Rose Sharply amid Pandemic: IWI.

https://www.indonesiawaterportal.com/news/water-consumption-rose-sharply-ami d-pandemic-iwi.html

[34] Kolota, A. and Glabska, D. (2021) COVID-19 Pandemic and Remote Education Contributes to Improved Nutritional Behaviors and Increased Screen Time in a 
Polish Population-Based Sample of Primary School Adolescents: Diet and Activity of Youth during COVID-19 (DAY-19) Study. Nutrients, 20, 1596.

https://doi.org/10.3390/nu13051596

[35] Ministry of Health (2021) Ministry of Health Invites All Parties to Campaign for Handwashing with Soap.

https://sehatnegeriku.kemkes.go.id/baca/umum/20201015/5435373/kemenkes-ajakpihak-kampanyekan-cuci-tangan-pakai-sabun

[36] Ministry of Health (2021) Washing Hands with Soap Reduces Diarrhea and ISPA Cases.

https://sehatnegeriku.kemkes.go.id/baca/rilis-media/20211013/2938725/cuci-tangan -pakai-sabun-turunkan-kasus-penyakit-diare-dan-ispa

[37] Ministry of Health (2008) Community Based Total Sanitation.

http://stbm.kemkes.go.id/app/about/1/about

[38] United States Agency for International Development (2010) USAID Indonesia Urban Water, Sanitation and Hygiene-Environmental Health for All (IUWASH Plus) WASH Gender Strategy.

https://www.iuwashplus.or.id/cms/wp-content/uploads/2020/06/IUWASH-PLUS-G ender-Strategy-after-USAID-review-FINAL.pdf

[39] Dwipayanti, N.M.U., Lubis, D.S. and Harjana, N.P.A. (2021) Public Perception and Hygiene Behavior during Covid-19 Pandemic in Indonesia. Frontiers in Public Health, 9, Article ID: 621800. https://doi.org/10.3389/fpubh.2021.621800

[40] Sianipar, E., Ridwan, M., Ibnu, I.N., Guspianto and Reskiadin, L.O. (2021) Factors Related to Hand Washing Behavior with Soap in Universitas Jambi Students during Covid-19 Pandemic. Jurnal Kesmas Jambi, 5, 55-61.

https://doi.org/10.22437/jkmj.v5i2.13693

[41] Usfar, A.A., Budiman, G., Lan, M.P.J., Riyanti, A. and Nuryanto, V.J. (2020) Balanced Nutrition Messages Are Still Implemented in Pre-Schools One Year PostIntervention: Case Studies in Subang District, West Java, Indonesia. Journal of $\mathrm{Nu}$ tritional Science and Vitaminology (Tokyo), 66, S155-S161. https://doi.org/10.3177/jnsv.66.S155

[42] Phan, M.C.J.L., Usfar, A. and Riyanti, A. (2021) Preschool Teachers Are Excellent Change Agents for Balanced Nutrition Messages to Students and Parents. (In Press)

[43] Yunianto, A.E., Kristiandi, K., Darawati, M., Doloksaribu, H., Anggraeni, I. and Pasambuna, M. (2021) Food Consumption Patterns among University Students in Indonesia during the Transition Period in New Normal Era of Covid-19 Pandemic. IOP Conference Series: Earth and Environmental Science, 883, Article ID: 012008. https://doi.org/10.1088/1755-1315/883/1/012008

[44] Food Organization Organization (2019) Six Ways Food Labels Are Helping You Be a Better You. https://www.fao.org/fao-stories/article/en/c/1177378

[45] World Health Organization (2020) Physical Activity: Key Facts. https://www.who.int/news-room/fact-sheets/detail/physical-activity

[46] Ammar, A., Brach, M., Trabelsi, K., Chtourou, H., Boukhris, O., Masmoudi, L., et al. (2020) Effects of COVID-19 Home Confinement on Eating Behaviour and Physical Activity: Results of the ECLB-COVID19 International Online Survey. Nutrients, 12, 1583. https://doi.org/10.3390/nu12061583

[47] Central Bureau of Statistics Indonesia (2019) National Research on Social Economic Subang.

[48] FAO (2021) Food-Based Dietary Guidelines.

https://www.fao.org/nutrition/education/food-dietary-guidelines/background/susta 
$\underline{\text { inable-dietary-guidelines/en }}$

[49] Post-2015 (2014) Consensus. Childhood Nutrition is the Most Critical and Economically Sound Intervention, Finds a New Study.

https://copenhagenconsensus.com/post-2015-consensus/news/childhood-nutritionmost-critical-and-economically-sound-intervention-finds

[50] Bhutta, Z.A., Das, J.K., Rizvi, A., Gaffey, M.F., Walker, N., Horton, S., et al. (2013) Evidence-Based Interventions for Improvement of Maternal and Child Nutrition: What Can Be Done and at What Cost? The Lancet, 382, 452-477.

https://doi.org/10.1016/S0140-6736(13)60996-4 